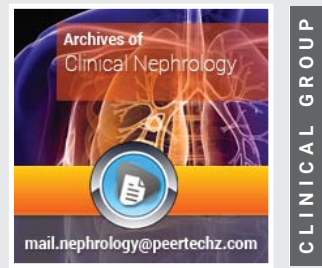

\title{
Pediatric Bartter syndrome: The therapeutic challenge
}

\author{
Aamir Jalal Al Mosawi ${ }^{1,2 \star}$ \\ ${ }^{1}$ Advisor in Pediatrics and Pediatric Psychiatry, Children Teaching Hospital, Baghdad Medical City, Iraq \\ ${ }^{2}$ Head, Iraq Headquarter of Copernicus Scientists International Panel, Baghdad, Iraq
}

Received: 20 December, 2019

Accepted: 04 February, 2020

Published: 06 February, 2020

*Corresponding author: Aamir Jalal Al Mosawi, Advisor in Pediatrics and Pediatric Psychiatry, Children Teaching Hospital, Baghdad Medical City, Iraq, E-mail: almosawiAJ@yahoo.com

Keywords: Classical; Pediatric; Bartter syndrome; Therapeutic challenge

https://www.peertechz.com

\section{Check for updates}

\begin{abstract}
Background: There is no curative therapy for many of the rare genetic disorders such as Bartter syndrome. Many patients with such disorders will be treated to a large extent with symptomatic therapies, and many of them will continue to have some symptoms, and growth and mental retardation despite the traditional therapies generally known by the treating physician. Because of the rarity of such disorders, many specialist physicians may have limited experience with treatment of such disorders and treatment side effects may be sometimes encountered. It is hoped that advances arising from the accumulating research evidence can contribute to improving treatment of such conditions.
\end{abstract}

Materials and methods: A unique case of classical pediatric Bartter syndrome associated with low set ears and mental retardation that was treated unsatisfactorily was studied. The medical literatures were reviewed for the recent research evidence that may help in improving the therapeutic services for patients with Bartter syndrome.

Results: The occurrence the rare genetic disorder Bartter syndrome in Iraq has not been documented. A unique case of Bartter syndrome associated with low set ears and mental retardation in an Iraqi girl. The girl was treated before referral by some of the traditional therapies that improved her symptoms and condition, but she experienced some side effects of treatment and growth and mental retardation.

Conclusion: Literature review helped in recommending an evidence-based opinion suggesting the replacement of one drug with a safer one, and the addition of another evidence-based effective therapy.

\section{Introduction}

Bartter syndrome is a rare genetic disorder characterized by hypokalemia, hypochloremia, alkalosis, and normal or low blood pressure. There are three main clinical forms of Bartter syndrome, and a variant form including neonatal Bartter syndrome, classical pediatric Bartter syndrome, adult Bartter syndrome and a variant form (Gitelman syndrome) which is generally milder than neonatal and classic pediatric forms of Bartter syndrome [1-3].

Children with classic Bartter syndrome generally became symptomatic in the first two years of life, but they are usually diagnosed at school age or later. Children with classic Bartter syndrome also develop polyuria, polydipsia, and a tendency to dehydration, but they generally have normal urinary calcium excretion or mild hypercalciuria without significant tendency to develop kidney stones [1].

\section{Other features of Bartter syndrome include [1]:}

Vomiting and growth retardation.
Renal function is generally normal.

Elevated plasma rennin and aldosterone.

$>$ High urinary potassium and chloride despite low serum values.

$>$ Hyperplasia of the juxtaglomerular apparatus on kidney biopsy.

$>$ Excess production of prostaglandins by the kidneys is often found.

There is no curative therapy for many of the rare genetic disorders such as Bartter syndrome. Many patients with such disorders will be treated to a large extent with symptomatic therapies, and many of them will continue to have some symptoms, and growth and mental retardation despite the traditional therapies generally known by the treating physician. Because of the rarity of such disorders, many specialist physicians may have limited experience with treatment of 
such disorders and treatment side effects may be sometimes encountered. It is hoped that advances arising from the accumulating research evidence can contribute to improving treatment of such conditions $[1,4,5]$.

\section{Materials and methods}

A unique case of classical pediatric Bartter syndrome associated with low set ears and mental retardation that was treated unsatisfactorily was studied. The medical literatures were reviewed for the recent research evidence that may help in improving the therapeutic services for patients with Bartter syndrome.

\section{Results}

The occurrence the rare genetic disorder Bartter syndrome in Iraq has not been documented. A unique case of Bartter syndrome associated with low set ears and mental retardation in an Iraqi girl. The girl was treated before referral by some of the traditional therapies that improved her symptoms and condition, but she experienced some side effects of treatment and growth and mental retardation. The girl was first seen at the pediatric psychiatry clinic at about the age of five years during June, 2018 as a known case of Bartter syndrome with poor speech development. She was also delayed in achieving motor mile stones. However, currently she can walk and run. The child had slow growth, episodes of vomiting, polydipsia, polyuria, and history of spasms. She has been treated with oral potassium supplementation (30mEq per day in divided doses) and indomethacin (12.5mg daily) which had to be stopped for some time before few months because of the development of serious gastric side effects with abdominal pain and vomiting.

Despite treatment, she had chronic hypokalemia as serum potassium was low in all the previously available performed tests (Table 1 ).

Although the girl had low set ears (Figure 1) and poor speech development, she was responding to her name, and had good eye contact. She responded when she asked to take the pen and try to copy a line, but she couldn't hold the pen perfectly right nor could she copy the line.

This Iraqi girl had been treated traditionally by potassium supplement and indomethacin, but persistent correction of hypokalemia couldn't be achieved.

\section{Bartter syndrome treatment research progress}

Bartter syndrome was originally treated by the physicians who first reported the condition, initially with potassium chloride supplements, and later they performed partial adrenalectomy. Symptoms were relieved for several months without potassium supplements after partial adrenalectomy, but serum potassium remained low (3.3-2.8mEq/L). Fifteen months after partial adrenalectomy, significant hypokalemia (Serum potassium: $2 \mathrm{mEq} / \mathrm{L}$ ) and tetany returned $[1,6,7]$.

George T Bryan and colleagues reported that spironolactone with low-sodium diet increased serum potassium to normal level in Bartter syndrome. They also reported that infusion of albumin was associated with a rapid increase in serum potassium and a reduction in aldosterone secretion rate [8].

The use of indomethacin has been reported by many authors including Verberckmoes, et al., Zancan and colleagues Littlewood and colleagues, Proesmans and colleagues, Dequiedt, et al., Kornerup and colleagues, Konomi, et al., Valles, et al., Floret, et al., Favre, et al., and Storm and colleagues [1,3,9-17].

The work of Kornerup and colleagues suggested that longterm treatment with indomethacin may be ineffective in maintaining normal potassium balance in Bartter syndrome [9]. Konomi, et al., reported the occurrence of pseudotumor cerebri in Bartter syndrome during indomethacin therapy [14]

The use of other inhibitors of prostaglandin synthetase in treatment of Bartter syndrome including ibuprofen $[18,19]$, aspirin [20], naproxen [21], ketoprofen were also reported $[22,23]$.

Gill JR, et al., reported that treatment with ibuprofen which is an inhibitor of prostaglandin synthetase having



Figure 1: The girl had low set ears.

Table 1: The previously available performed tests

\begin{tabular}{|c|c|c|c|c|c|c|c|c|c|}
\hline Date & $\begin{array}{c}\text { Serum } \\
\text { Potassium } \\
\mathrm{mEq} / \mathrm{L}\end{array}$ & $\begin{array}{c}\text { Serum chloride } \\
\mathrm{mEq} / \mathrm{L}\end{array}$ & Blood PH & $\begin{array}{c}\text { Serum bicarb } \\
\mathrm{mEq} / \mathrm{L}\end{array}$ & $\begin{array}{c}\text { Serum sodium } \\
\mathrm{mEq} / \mathrm{L}\end{array}$ & PCO2 & $\begin{array}{c}\text { Serum } \\
\text { Creatinine } \\
\text { mg/dL }\end{array}$ & $\begin{array}{c}\text { Blood } \\
\text { urea } \mathrm{mg} / \mathrm{dL}\end{array}$ & $\begin{array}{l}\text { Serum } \\
\text { calcium }\end{array}$ \\
\hline Jan, 22, 2017 & 2.3 & 88 & & & & & & & \\
\hline Jan, 31, 2017 & 2.3 & 96 & 7.39 & & & & & & \\
\hline May, 8, 2017 & 2.9 & 92 & 7.428 & 24.7 & 135 & 36.9 & 0.36 & & \\
\hline Jul, 6, 2017 & 2.2 & 96 & 7.49 & 27.8 & 139 & 36.7 & 0.34 & $24 \mathrm{mg}$ & 10.1 \\
\hline Sept, 28, 2018 & 2.2 & 95 & & & 137 & & 0.36 & & \\
\hline
\end{tabular}


different structure from indomethacin was associated with metabolic effects which were qualitatively similar to those of indomethacin [18].

Norby, et al., treated a young patient with Bartter syndrome was for three months with $100 \mathrm{mg} / \mathrm{kg} /$ day of aspirin to inhibit prostaglandin synthesis. Treatment was associated with disappearance of clinical symptoms and elevation of serumpotassium from 2.9 to $3.5 \mathrm{mmol} / \mathrm{l}$. Norby, et al., thought that overproduction of prostaglandins has a central role in the pathogenesis of Bartter syndrome [20].

Littlewood and colleagues reported a nine-month old boy with Bartter syndrome who had poor weight and height gain. They treated him initially with oral potassium supplements and later with spironolactone which restored plasma potassium to normal. However, the patient experienced little or no effect on his growth. At the age of thirty-three months, indomethacin therapy was started, and was associated with dramatic results. Symptoms disappeared, and his height and weight accelerated to reach the normal range. Because of the toxicity of indomethacin, Littlewood and colleagues replaced it after twelve months by another prostaglandin synthetase inhibitor, ketoprofen. The use of ketoprofen was associated with a satisfactory result. Littlewood and colleagues thought that treatment with prostaglandin synthetase inhibitors is the best available treatment for Bartter syndrome [22].

Larizza, et al., reported the occurrence of pseudotumor cerebri during ketoprofen treatment in Bartter syndrome [23].

Simatupang, et al., studied the effect of anti-kaliuretic agents (spironolactone, amiloride) and antiprostaglandin agents (indomethacin, ibuprofen) on plasma rennin activity and potassium metabolism in a patient with familial Bartter syndrome. They reported the followings [24].

* The reduction in renal potassium clearance in response to antikaliuretic treatment was transient, whereas marked potassium retention occurred with indomethacin therapy.

* Plasma rennin activity consistently increased after kaliuretics, while a marked reduction occurred in response to antiprostaglandin agents.

Cunningham, et al., reported the treatment of two patients with Bartter syndrome with propranolol, spironolactone, and potassium supplements initially. The addition of ibuprofen made potassium supplements no longer required. In both patients, plasma rennin activity was reduced, plasma volumes increased, and a "catch-up" in linear growth resulted. The report of Cunningham, et al., emphasized the value of the prostaglandin synthetase inhibitor, ibuprofen in the therapy of Bartter syndrome [25].

The treatment of Barter syndrome with angiotensin converting enzyme inhibitor has been reported by several authors including Aurell and Rudin, Hené, et al., Aurell and Rudin, Hené, et al., Morales, et al., Volpi, et al., Scherling, et al., [26-33].
Hené, et al., treated seven patients with Bartter syndrome for three months by enalapril. Treatment was associated with elevation of Serum potassium from $2.4+/-0.5$ to $3.9+/-0.6 \mathrm{mmol} / \mathrm{L}$, elevation of serum magnesium and lowering of serum bicarbonate, stimulation of rennin and reduction of aldosterone. Lowering of blood pressure. Clinically important short-lasting hypotension associated with oliguria was recorded twice. Blood pressure returned to pre-treatment levels within 72hours despite continuation of converting-enzyme inhibition. Renal function recovered, though a moderate fall in function persisted. No other side effects were recorded by Hené, et al., Hené, et al., thought that converting-enzyme inhibition can improve the potassium metabolism of patients with Bartter syndrome without improving the abnormal renal sodium handling [29].

Van de Stolpe, et al., studied total body potassium in three patients with Bartter syndrome before, after three months and after 1 year of treatment with enalapril. In two patients, total body potassium was reduced before treatment, whereas total body potassium was within the normal range in the third measurement. During treatment serum potassium and total body potassium increased in each patient, and the symptoms of fatigue and tetany disappeared. Van de Stolpe, et al., thought that enalapril can be effective in the treatment of Bartter syndrome as it improves serum potassium, total body potassium and symptoms [30].

Volpi, et al., reported the long-term treatment of three sisters with Bartter syndrome with captopril therapy [31].

Scherling, et al., from Denmark reported the treatment of a thirteen years old girl with Bartter syndrome who had [33].

* Lassitude and polyuria.

* Hypokalemia.

* Elevated plasma rennin and urinary prostaglandin excretion.

* Normal plasma aldosterone level and normal urinary aldosterone excretion.

* Normal blood pressure.

The initial treatment of the patient with oral potassium was not satisfactory.

Treatment with acetylsalicylic acid was associated with some effect, and an allergic reaction led withdrawal of treatment. Treatment with the angiotensin converting enzyme inhibitor captopril and oral potassium was associated with clinical and biochemical improvement.

\section{Discussion}

Bartter syndrome was probably first described by Pacita Pronove, Ross C MacCardle and Frederic Crosby Bartter in 1960. They reported a five-year old boy with hypokalemia, alkalosis, primary aldosteronism, normal blood pressure, unique renal lesion which is hyperplasia of the juxtaglomerular apparatus. 
In 1962, Frederic Crosby Bartter, Pacita Pronove, John R Jill Jr, and Ross C MacCardle published a paper emphasizing that the condition which was described earlier by three of them in 1960 was a new syndrome. Frederic Crosby Bartter and his team also described a second black male patient. Frederic Crosby Bartter and his team considered the two patients they described as having a new syndrome $[1,6,7]$. Bartter syndrome was classically and originally associated with hyperplasia of the juxtaglomerular apparatus of the kidneys. However, several patients with Bartter syndrome have been reported without evidence of hyperplasia of the juxtaglomerular apparatus $[1,9,34]$.

The Iraqi girl being reported had mental retardation and low set ears. Simopoulos reviewed the literature and found that the majority of patients with Bartter syndrome showed some degree of mental retardation. However, low set ears has not been reported with this syndrome [35].

The paper of Kornerup and colleagues suggested that long-term treatment with indomethacin may be ineffective in maintaining normal potassium balance in Bartter syndrome [9]. Konomi, et al., reported the occurrence of pseudotumor cerebri in Bartter syndrome during indomethacin therapy [15].

Gill JR, et al., reported that treatment with ibuprofen which is an inhibitor of prostaglandin synthetase having different structure from indomethacin was associated with metabolic effects which were qualitatively similar to those of indomethacin [18].

Cunningham, et al., emphasized the value of the prostaglandin synthetase inhibitor, ibuprofen in the therapy of Bartter syndrome.

Therefore, the available evidence suggests replacing indomethacin with ibuprofen.

I am reluctant to recommend adding anti-kaliuretic agents (spironolactone or amiloride) to the treatment of the girl because Simatupang, et al., studied the effect of anti-kaliuretic agents (spironolactone, amiloride), and antiprostaglandin agents (indomethacin, ibuprofen) on plasma rennin activity and potassium metabolism in a patient with familial Bartter syndrome, and reported that the reduction in renal potassium clearance in response to antikaliuretic treatment was transient, whereas marked potassium retention occurred with indomethacin therapy [24].

Plasma rennin activity consistently increased after kaliuretics, while a marked reduction occurred in response to anti-prostaglandin agents. There is also convincing evidence that the addition of enalapril can be of value in improving treatment in this Iraqi patient [30].

\section{Conclusion}

Literature review helped in recommending an evidencebased opinion suggesting the replacement of one drug with a safer one, and the addition of another evidence-based effective therapy.

\section{Acknowledgement}

The author would to express his gratitude for the parents of the patient who accepted publishing her photo.

\section{References}

1. Al-Mosawi AJ (2018) Classical pediatric Bartter syndrome with low set ears $1^{\text {st }}$ ed., Saarbrücken; LAP Lambert Academic. Link: http://bit.ly/397KCcJ

2. Tomko DK, Yeh BP, Falls WF (1976) Bartter's syndrome. Study of a 52 year old man with evidence for a defect in proximal tubular sodium reabsorption and comments on therapy. Am J Med 61: 111-118. Link: http://bit.ly/3823w4T

3. Favre L, Glasson P, Flory ED, Dray F, Vallotton MB (1979) Bartter's syndrome: Recurrence in the course of a treatment inhibiting prostaglandin synthesis. Schweiz Med Wochenschr 109: 142-147. Link: http://bit.ly/3bdaztr

4. Al-Mosawi AJ (2019) Genetic and Hereditary Disorders in Iraqi Children. Ann Med Surg Case Rep 1: 1-8. Link: http://bit.ly/2vUGdff

5. Al-Mosawi AJ (2019) The uncommon and rare genetic disorders in Iraq. $1^{\text {st }}$ ed. Saarbrücken; LAP Lambert Academic Publishing:. Link: http://bit.ly/36T6FCE

6. Pronove P, MacCardle RC, Bartter FC (1960) Aldosteronism, hypokalemia and a unique renal lesion in a five year old boy. Acta Endocr 167. Link: http://bit.ly/31wuhfo

7. Bartter FC, Pronove P, Gill JR, MacCardle RC (1962) Hyperplasia of the juxtaglomerular complex with hyperaldosteronism and hypokalemic alkalosis. A new syndrome. Am J Med 33: 811-828. Link: http://bit.ly/384PRKg

8. Bryan GT, MacCardle RC, Bartter FC (1966) Hyperaldosteronism, hyperplasia of the juxtaglomerular complex, normal blood pressure, and dwarfism: report of a case. Pediatrics 37: 43-50. Link: http://bit.ly/31rHR3v

9. Kornerup HJ, Pedersen EB, Petersen VP (1978) Bartter's syndrome without hyperplasia of the juxtaglomerular apparatus, treated with indomethacin. Acta Med Scand 204: 235-239. Link: http://bit.ly/31sLN3X

10. Littlewood JM, Lee MR, Meadow SR (1976) Treatment of childhood Bartter's syndrome with indomethacin. Lancet 2: 795. Link: http://bit.ly/2vSdWG2

11. Zancan L, Zacchello F, Mantero F (1976) Indomethacin for Bartter's syndrome Lancet 308: 1354. Link: http://bit.ly/2v2gJMv

12. Verberckmoes $R$, van Damme $B B$, Clement $J$, Amery $A$, Michielsen $P$ (1976) Bartter's syndrome with hyperplasia of renomedullary cells: successful treatment with indomethacin. Kidney Int 9: 302-307. Link: http://bit.ly/3828MWb

13. Proesmans W, Muaka BK, Monnens L (1977) Indomethacin therapy in Bartter syndrome. Acta Paediatr Belg 30: 31-36. Link: http://bit.ly/3b6mj0G

14. Dequiedt P, Lefebvre J, Raviart B, Vanhille P, Lepoutre E, et al. (1977) Value and limitations of indomethacin in the treatment of Bartter's syndrome. J Uro Nephrol (Paris) 83: 688-693. Link: http://bit.ly/20v8Sh7

15. Konomi H, Imai M, Nihei K, Kamoshita S, Tada H (1978) Indomethacin causing pseudotumor cerebri in Bartter's syndrome. N Engl J Med 298: 855. Link: http://bit.ly/39dpi5V

16. Valles M, Botey A, Bergada E, Revert L (1978) Indomethacin in Bartter's syndrome. Rev Clin Esp 149: 601-605. Link: http://bit.ly/2v87t9m

17. Floret D, David M, Roux A, Hage GN, Teyssier G (1979) Bartter's syndrome: the long term effects of indomethacin on growth. Nouv Presse Med 8: 17-21. Link: http://bit.ly/2twcsQZ

18. Gill JR, Frölich JC, Bowden RE, Taylor AA, Keiser HR, et al. (1976) Bartter's syndrome: a disorder characterized by high urinary prostaglandins and a dependence of hyperreninemia on prostaglandin synthesis. Am J Med 61: 43 51. Link: http://bit.ly/2RYkjjG 
19. Lechacz G, Arbus GS, Balfe JW, Wolff ED, Robson L (1979) Effect of ibuprofen on growth in a child with Bartter syndrome. J Pediatr 95: 313-316. Link: http://bit.ly/2S3nKWt

20. Norby L, Flamenbaum W, Lentz R, Ramwell P (1976) Prostaglandins and aspirin therapy in Bartter's syndrome. Lancet 308: 604-606. Link: http://bit.ly/37ZEd3b

21. Katz FH, Bortz Al (1978) Treatment of Bartter's syndrome with naproxen. N Engl J Med 299: 100. Link: http://bit.ly/2GSPxT0

22. Littlewood JM, Lee MR, Meadow SR (1978) Treatment of Bartter's syndrome in early childhood with prostaglandin synthetase inhibitors. Arch Dis Child 53 : 43-48. Link: http://bit.ly/20u7J9Q

23. Larizza D, Colombo A, Lorini R, Severi F (1979) Ketoprofen causing pseudotumor cerebri in Bartter's syndrome. N Engl J Med 300: 796. Link: http://bit.ly/2OvTNfc

24. Simatupang TA, Radó JP, Boer P, Geyskes GG, Vos J, et al. (1978) Pharmacologic studies in Bartter's syndrome: opposite effects of treatment with antikaliuretic and antiprostaglandin drugs. Part I. Int J Clin Pharmacol Biopharm 16: 14-18. Link: http://bit.ly/2GULHIZ

25. Cunningham RJ, Brouhard BH, Berger M, Petrusick T, Travis LB (1979) Longterm use of propranolol, ibuprofen, and spironolactone in the management of Bartter's syndrome. Pediatrics 63: 754-746. Link: http://bit.ly/380YZj7

26. Aurell M, Rudin A (1981) Effects of captopril in Bartter's syndrome. N Engl J Med 304: 1609. Link: http://bit.ly/2vMNhdv

27. Hené RJ, Koomans HA, Boer P, Dorhout Mees EJ (1982) Long-term treatment of bartter's syndrome with captopril. Br Med J 285: 695. Link: http://bit.ly/2SOzDwg

28. Aurell M, Rudin A (1985) Effect of captopril in Bartter's syndrome. Nephron 39: 68

29. Hené RJ, Koomans HA, Dorhout Mees EJ, vd Stolpe A, Verhoef GE, et al. (1987) Correction of hypokalemia in Bartter's syndrome by enalapril. Am J Kidney Dis 9: 200-205. Link: http://bit.ly/31wAiJ0

30. van de Stolpe A, Verhoef GE, Hené RJ, Koomans HA, van der Vijver JC (1987) Total body potassium in Bartter's syndrome before and during treatment with enalapril. Nephron 45: 122-125. Link: http://bit.ly/372bVUm

31. Volpi A, Meroni M, Battini G, Torri-Tarelli L, Conte F, et al. (1988) Long-term captopril therapy of S sisters with Bartter's syndrome. Minerva Urol Nefrol 40 61-66. Link: http://bit.ly/2UrhOlk

32. Morales JM, Ruilope LM, Praga M, Coto A, Alcazar JM, et al. (1988) Long term enalapril therapy in Bartter's syndrome. Nephron 48: 327. Link: http://bit.ly/31pypxE

33. Scherling B, Verder H, Nielsen MD, Christensen P, Giese J (1990) Captopril treatment in Bartter's syndrome. Scand J Urol Nephrol 24: 123-125. Link: http://bit.ly/2twe8df

34. Barakat AY, Francis YK, Mufarrij AA (1986) Hypokalemic alkalosis hyperreninemia, aldosteronism, normal blood pressure and norma juxtaglomerular apparatus: a new syndrome of renal alkalosis. Int J Pediatr Nephrol 7: 99-100. Link: http://bit.ly/3764yeY

35. Simopoulos AP (1979) Growth characteristics in patients with Bartter's syndrome. Nephron 23: 130-135. Link: http://bit.ly/2SiqRIY

Discover a bigger Impact and Visibility of your article publication with Peertechz Publications

\footnotetext{
Highlights

* Signatory publisher of ORCID

* Signatory Publisher of DORA (San Francisco Declaration on Research Assessment)

* Articles archived in worlds' renowned service providers such as Portico, CNKI, AGRIS TDNet, Base (Bielefeld University Library), CrossRef, Scilit, J-Gate etc.

* Journals indexed in ICMJE, SHERPA/ROMEO, Google Scholar etc.

* OAI-PMH (Open Archives Initiative Protocol for Metadata Harvesting)

* Dedicated Editorial Board for every journal

* Accurate and rapid peer-review process

- Increased citations of published articles through promotions

- Reduced timeline for article publication

Submit your articles and experience a new surge in publication services (https://www.peertechz.com/submission).
}

Peertechz journals wishes everlasting success in your every endeavours.

Copyright: @ 2020 Al Mosawi AJ, et al. This is an open-access article distributed under the terms of the Creative Commons Attribution License, which permits unrestricted use, distribution, and reproduction in any medium, provided the original author and source are credited. 